\title{
PENGEMBANGAN BAHAN AJAR E-BOOK PRAKTIKUM AKUNTANSI PERUSAHAAN DAGANG BERBASIS SCIENTIFIC APPROACH SEBAGAI SUMBER BELAJAR ALTERNATIF
}

\section{DEVELOPMENT OF E-BOOK TEACHING MATERIALS PRACTICUM ACCOUNTING TRADING COMPANY BASED ON SCIENTIFIC APPROACH AS ALTERNATIVE LEARNING RESOURCES}

Oleh:

\author{
Rizka Wahyu Candra Kirana \\ Pendidikan Ekonomi, Fakultas Ekonomi, Universitas Negeri Surabaya, \\ rizkakirana16080304035@mhs.unesa.ac.id \\ Joni Susilowibowo \\ Pendidikan Ekonomi, Fakultas Ekonomi, Universitas Negeri Surabaya, \\ jonisusilowibowo@unesa.ac.id
}

\begin{abstract}
Abstrak
Pembelajaran yang efektif dan efisien dapat diwujudkan dengan adanya ketersediaan bahan ajar penunjang yang menyokong serta memadai. E-book merupakan bahan ajar inovatif berbentuk digital sebagai bentuk pembaharuan pemanfaatan hasil teknologi yang berguna dalam proses pembelajaran. Penelitian ini bertujuan mengembangkan bahan ajar $e$-book pada mata pelajaran praktikum akuntansi perusahaan dagang berbasis scientific approach. Tujuan penelitian yaitu menganalisis $e$-book yang dikembangkan dan menganalisis tingkat kelayakan $e$-book. Model pengembangan dalam penelitian ini menggunakan model pengembangan fourD dari Thiagajaran, Semmel dan Semmel mulai dari langkah pendefinisian sampai langkah pengembangan. Hasil penelitian menunjukan hasil rata-rata kelayakan yang diperoleh dari validator ahli bidang sebesar 85,6\% dengan kriteria "sangat layak". Komponen validator bidang materi mendapatkan hasil sebesar 85,9\% dengan kriteria sangat layak, komponen validator bidang Bahasa mendapatkan hasil sebesar 83,7\% dengan kriteria sangat layak dan komponen validator bidang grafis mendapatkan hasil sebesar $87,3 \%$ dengan kriteria sangat layak. Data tersebut diperoleh dari lembar validasi ahli bidang yang berisi kriteria penilaian menggunakan skala likert melalui angket tertutup, hasilnya diolah dan diinterprestasikan sesuai kriteria tingkat kelayakan $e$-book. Kesimpulan penelitian ini $e$-book praktikum akuntansi perusahaan dagang berbasic scientific approach "sangat layak" dimanfaatkan dalem proces pembelajaran sebagai sumber belajar alternatif.
\end{abstract}

Kata Kunci: Bahan Ajar E-book; Model Pengembangan four-D; Scientific Approach

\section{Abstract}

Effective and efficient learning can be realized with the availability of supporting and adequate teaching materials. E-books are innovative digital teaching materials as a form of renewal of the use of technology results that are useful in the learning process. This research aims to develop e-book teaching materials on subjects of accounting practice for trading companies based on scientific approach. The research objective is to analyze the e-book that 
was developed and analyze the level of eligibility of the e-book. The development model in this research uses the 4-D developtment model from Thiagajaran, Semmel and Semmel, starting from the definding stage to the development stage. The results showed the average results of elgibility obtainned from experts amounted to $85.6 \%$ with very decdent criteria. The feasibility conponent of the material field gets a result of $85.9 \%$ with very dedcent criteria, the feasibility component of the Language field gets a result of $83.7 \%$ with a very decdent criterion and the component of the feasibility component of the graphic field gets a result of $87.3 \%$ with a very decdent criterion. Data obtained from field expert validation sheets containing assessment criteria using a Likert scale through a closed questionnaire, the results are processed and interpreted in accordance with the eligibility level of the e-book. The conclusion of this research e-book accounting practice trading company based on scientific approach "very feasible" is used in the learning process as an alternative learning source.

Keywords: E-book teaching materials; four-D Development Model; Scientific Approach

\section{PENDAHULUAN}

Pendidikan secara umum didefinisikan sebagai pengalaman belajar yang dilakukan sepanjang hidup, sedangkan dalam arti lebih sempit yakni sekolah sebagai lembaga formal yang menyelenggarakan pengajaran. Sesuai Undang-Undang Republik Indonesia Nomor 20 Tahun 2003 pasal 1 ayat (1) mengenai sistem pendidikan nasional, pemerintah telah memfasilitasi pendidikan dengan membuka jalur pendidikan formal, non-formal maupun informal guna mencukupi dan menambah pengetahuan. Sekolah menengah kejuruan (SMK) merupakan satu dari beberapa macam jenjang pendidikan formal. Menurut Kemendikbud (2018) tentang standar nasional Pendidikan SMK/MAK, peserta didik diharapakan mampu menyesuaikan diri dengan mudah dengan adanya perubahan teknologi serta lingkungan dan dapat menumbuhkan nilai diri sebagai sumber daya manusia yang memiliki daya saing serta berkualitas di berbagai sektor yang telah berkembang. Sekolah menengah kejuruan menyiapkan lulusannya secara eksklusif agar terlatih dan memiliki keterampilan. Oleh karenanya, sekolah menengah kejuruan dalam proses pembelajarannya memadukan ilmu pengetahuan (hard skill) maupun keterampilan (soft skill).

Kualitas pembelajaran menjadi fokus utama dalam bidang pendidikan sebab kualitas pembelajaran mencerminkan baik dan buruknya kualitas pendidikan dalam suatu negara. Kualitas pendidikan yang baik dapat dicapai apabila perancangan kurikulum serasi dengan tujuan pendidikan serta digunakan sebagai dasar pelaksanaan kegiatan pembelajaran. Kurikulum menjadi pijakan sistem pendidikan di Indonesia adalah kurikulum. Kurikulum diberlakukan dan diterapkan pada Pendidikan saat ini yaitu kurikulum 2013 spektrum atau edisi revisi. Menurut Pratiwi (2019) kurikulum 2013 edisi revisi berpikiran kalau guru dan peserta didik merupakan satu kesatuan dan ilmu pengetahuan tidak bisa berpindah secara langsung. Penerapan kurikulum 2013 ini dengan maksud keterampilan-keterampilan serta potensi yang dimiliki peserta didik mampu ditingkatkan, ditumbuhkan, dan dielaborasikan. Ada lima keterampilan yang dikembangkan dalam pelaksanaan kurikulum 2013, yaitu berupa keterampilan proses atau biasa disebut dengan pembelajaran 5M yakni mengamati, menanya, mengumpulkan informasi, mengasosiasi atau menganalisis dan mengkomunikasikan pengetahuan yang diperoleh atau dikenal dengan pembelajaran berbasis scientific approach. J.G.Dyer and C.M.Christensen menyebutkan (dalam Pratiwi, 2019) pembelajaran berbasis scientific approach ialah kegiatan belajar mengajar di dalamnya memuat lima proses berpikir dalam mendapatkan pengetahuan yakni mengobservasi, menanya, mencoba, menghubungkan/menalar, dan menghubungkan jaringan. Undang-Undang Republik Indonesia Nomor 20 Tahun 2003 menyebutkan kurikulum ialah pedoman penyelenggaraan pembelajaran 
yang berisi seperangkat rancangan dan pengendalian mengeni tujuan, isi, cara, dan bahan pengajaran guna menggapai tujuan penddikan. Pengembangan kurikulum dapat dilaksanakan dengan perpedoman pada standar pendidikan demi terwujudnya tujuan pendidikan nasional.

Guna mendukung proses pembelajaran, bahan ajar adalah sumber belajar yang sangat dibutuhan peserta didik dan guru sebagai peranti belajar. Menurut Prastowo (2015), sumber belajar yang tersusun dengan sistematis, memuat kompetensi yang harus dimiliki peserta didik serta diterapkan dalam proses pembelajaran guna terwujudnya tujuaan rancangan dan pengkajian penerapan pembelajaran disebut dengan sumber belajar. Oleh karenanya, pembelajaran yang baik memerlukan bahan ajar yang baik pula. Menurut Rahmawati (2019), bahan ajar ialah komponen yang sangat krusial dalam proses pelaksanaan pembelajaran, sebab bahan ajar mampu mempermudah guru dan peserta didik mempelajari kompetensi yang dimuat, sehingga bahan ajar harus dirumuskan serta dibuat secara tersistem. Bahan ajar yang diintegrasikan dengan scientific approach lebih efektif dan efisien diterapkan, sebab peserta didik lebih mudah mengerti materi, memperluas cara berpikir kreatif, lebih bertindak aktif dalam proses pengajaran. Hal tersebut didukung oleh penelitian Raihan (2018), Fadhilah (2019) dan Huda (2017) yang menunjukan bahan ajar jika dikonsolidasikan dengan scientific approach akan meningkatkan kapabilitas dan kapasitas ilmu pengetahuan peserta didik. Guna menghasilkan proses belajar mengajar yang tepat guna, perlu adanya penyokong yang kontributif dan akseptabel. Salah satu penumpu proses pembelajaran ialah ketersediaan bahan ajar/buku untuk dimanfaatkan peserta didik dalam memperdalam materi yang diperoleh. Namun, berkembangnya teknologi dan zaman yang semakin pesat juga menuntut guru untuk menggunakan teknologi guna mengoptimalkan tujuan pembelajaran dalam proses pembelajaran. Sehingga, salah satu pendayagunaan teknologi yang bisa diusahakan oleh guru yaitu menggunakan bahan ajar elektronik sebagai usaha penciptaan pemanfaatan hasil teknologi dalam proses pembelajaran. Bahan ajar inovatif bisa diciptakan dengan mendayagunakan teknologi dan informasi sehingga bahan ajar tersebut menarik dan dapat difungsikan secara optimal guna meningkatkan kualitas pembelajaran. Peran bahan ajar inoyatif dapat menggerakkan minat peserta didik untuk aktif, mandiri dan meningkatkan kemampuan literasi yang dimiliki.

Bahan ajar memiliki berbagai bentuk, Lestari (dalam Pratiwi, 2019) mengungkapkan bahwa bahan ajar dibagi atas bahan ajar cetak dan noncetak. Bahan ajar non-cetak satu jenisnya yakni elektronic book atau digital book. Buku digital yakni buku yang tidak dicetak dan memuat teks, gambar atau kombinasi (Supanda, 2013). Menurut Ahmadi (2018) e-book adalah bahan ajar inovatif dalam bentuk non-cetak yang bentuknya menyerupai buku cetak namun produk dalam bentuk file lunak sehingga dapat didistribusikan efisien dan ekonomis untuk mengatasi keterbatasan buku cetak. Penggunaan $e$-book memiliki beberapa keunggulan yaitu mengikuti perkembangan zaman, mudah diakses, mudah disebarkan, tidak mudah lapuk, mudah dibawa dan digunakan. Dengan adanya sumber belajar pendukung berupa e-book diharapkan dapat membuat proses pelaksanaan pembelajaran lebih tepat guna. Hal tersebut seperti yang dinyatakan oleh Darmawan (dalam Pratiwi, 2019) bahwa program pembelajaran yang berbasis komputer mempunyai kelebihan dibanding bahan pembelajaran cetak biasa.

Berdasarkan hasil wawancara yang telah diperoleh dari guru pengajar mata pelajaran praktikum akuntansi perusahaan dagang, di SMKN 1 Surabaya, guru berpandangan bahwa mata pelajaran tersebut tergolong pengajian yang penting terlebih-lebih pada praktikum akuntansi perusahaan dagang yang terdapat pada KD 3.9 sampai KD 3.19. Hal tersebut dikarenakan peserta didik nantinya akan melakukan ujian kompetensi keahlian yang materinya adalah siklus akuntansi perusahaan dagang. Sedangkan hasil pengamatan terhadap peserta didik, disimpulkan bahwa peserta didik berpendapat jika mata pelajaran praktikum akuntansi perusahaan dagang merupakan bidang kajian yang sukar. Peserta didik juga sulit memahami dan menginterpretasikan kajian teori apabila tidak dijelaskan oleh guru walaupun telah diberikan 
buku pegangan.

Berdasarkan observasi, dapat disimpulkan terdapat dua hal pokok permasalahan yang terjadi pada guru peserta didik dan menjadi penyebab utama kesulitan belajar peserta didik, pertama dari segi materi, untuk menyelesaikan siklus akuntansi perusahaan dagang peserta didik harus mengedepankan cara berpikir yang logis. Kedua, menurunnya semangat peserta didik untuk belajar dengan lebih mandiri sebab ketersediaan bahan ajar yang mempermudah pemahaman dan meningkatkan semangat belajar dengan mandiri dan aktif peserta didik. Peserta didik selalu bergantung dari penjelasan guru dan cenderung ingin dituntun saat mengerjakan. Padahal menyajikan pembelajaran yang inovatif dan peserta didik menjadi pusatnya merupakan tugas seorang guru.

Untuk menangani permasalahan tersebut, perlu dikembangkan bahan ajar pendamping yang menitik beratkan dalam memuat contoh penerapan pencatatan transaksi perusahaan dagang yang disajikan saling berkaitan setiap babnya agar peserta didik lebih mudah memahami siklus akuntansi atau alur pencatatan transaksi perusahaan dagang mulai dari pencatatan dokumen sumber ke dalam berbagai jurnal sampai dengan membuat laporan keuangan perusahaan secara sistematis dan benar. Pengembangan bahan ajar pendamping ini menjadi tujuan untuk menunjang peserta didik dalam menggali informasi yang disusun secara integratif dan berbasis teknologi agar peserta didik lebih terbaharui sebab tidak terhindarkan bahwa dunia pendidikan tidak terlepas dari pengaruh teknologi. Pengembangan $e$-book ini diharapkan dapat menunjang proses pembelajaran pada mata pelajaran praktikum akuntansi perusahaan dagang di kelas, mepermudah peserta didik dalam memahami keseluruhan materi sesuai kompetensi dasar, dapat manfaatkan peserta didik untuk belajar lebih bebas, mandiri, dapat dipakai dengan terorganisir kapan saja serta dimana saja dan digunakan belajar sesuai dengan kecepatan belajarnya. Sehingga peserta didik lebih faham dan menyerap pengetahuan pada mata pelajaran tersebut secara optimal. Untuk memermudah pehamaman peserta didik, bahan ajar e-book disusun dengan sistematis berpatokan kurikulum 2013 atau berbasis scientific approach yang hanya merujuk pada sintak mengumpulkan informasi. Bahan ajar disajikan dengan bahasa yang mudah dipahami. Bahan ajar ini dapat diakses offline melalui komputer, laptop dan handphone. Bahan ajar $e$-book ini disusun sesuai dengan standart kelayakan $e$-book menurut BSNP.

Penelitian terdahulu yang relevan dengan bahan ajar e-book yang dikembangkan diantaranya penelitian yang dilaksanakan oleh Dewi (2017) dengan nilai kelayakan bahan ajar tergolong "sangat layak" serta respons peserta didik sangat baik. Rahmawati (2019) dengan nilai kelayakan bahan ajar para ahli menunjukan kelayakan isi tergolong sangat layak, Bahasa sangat layak, kegrafisan sangat layak dan respons peserta didik "sangat memahami". Penilitian lain dilakukan oleh Pratiwi (2019) dengan nilai kelayakan bahan ajar menunjukan kelayakan isi, penyajian, Bahasa, dan kegrafikan menunjukan sangat layak serta respon peserta didik sangat memahami.

Berdasar pada pemaparan yang telah dijelaskan di atas, peneliti memutuskan melaksanakan penelitian dengan judul "Pengembangan Bahan Ajar Ebook Praktikum Akuntansi Perusahaan Dagang Berbasis Scientific Approach sebagai Sumber Belajar Alternatif." Rumusan masalah yang dapat disusun dari penelitian ini sebagai berikut, (1) Bagaimana proses pengembangan bahan ajar e-book praktikum akunatnsi berbasis scientific approach sebagai sumber belajar alternatif? (2) Bagaimana kelayakan bahan ajar $e$-book praktikum akuntansi perusahaan dagang berbasis scientific approach sebagai sumber belajar alternatif? sedangkan tujuan penelitian pengembangan ini yang berdasar pada rumusan masalah yang telah disusun adalah sebagai berikut, (1) Menganalisis produk bahan ajar e-book praktikum akuntansi perusahaan dagang berbasis scientific approach sebagai sumber belajar alternatif yang telah dikembangkan. (2) Menganalisis kelayakan bahan ajar e-book praktikum akuntansi perusahaan dagang berbasis scientific approach sebagai sumber belajar alternatif yang telah dikembangkan. 


\section{METODE PENELITIAN}

Model yang diterapkan dalam penelitian ini yakni penggunaan model Research and Development (R\&D) yaitu studi atau riset mencetuskan ciptaan yang telah teruji keefektifannya. Hasyim (2015) mengutarakan intensitas penelitian Research and Development (R\&D) yakni meluaskan, menilai manfaat serta efisiensi ciptaan yang telah ada. Baik berupa ciptaan teknologi, model, alat bantu, dan lain sebagainya.

Metode pengembangan 4-D pada teori Thiagarajan, Semmel and Semmel menjadi tumpuan dalam penelitian ini (Trianto, 2015). Model pengembangan 4-D terdiri empat tingkatan yakni define atau pendefinisian, design atau perancangan, pengembangan atau develop, dan penyebaran atau disseminate. Penggunaan desain ini berdasar pandangan, model 4-D mempunyai tahapan atau langkah penelitian yang terstruktur dan tahapannya serasi dengan individualitas penelitian yang dilakukan. Penelitian ini berakhir sampai tahap develop.

Subjek uji coba adalah dosen S1 Pendidikan Akuntansi Unesa dan guru akuntansi yang andal dibidang praktikum akuntansi perusahaan dagang sebagai ahli materi, dosen Fakultas Bahasa Unesa yang andal dalam bidang tata Bahasa Indonesia menjadi validator Bahasa dan dosen Fakultas Ilmu Pendidikan Unesa yang andal dalam bidang kegrafisan sebagai validator grafis.

Jenis data kuantitatif dan kualitatif didapatkan pada penelitian ini. Lembar penelaahan bidang menghasilkan data kualitatif dan lembar validasi bidang menghasilkan data kuantitatif. Kedua data tersebut akan diolah dan dipersentasikan untuk mendapatkan hasil interprestasi kelayakan bahan ajar $e$-book.

Menghimpun data kualitatif dan kuantitatif memerlukan instrumen pengumpulan data. Riduwan (2016) menyatakan untuk mempermudah dan supaya lebih sistematis peneliti dapat memakai instrumen pengumpulan data sebagai alat bantu. Sedangkan menurut Sugiyono (2016) instrumen penelitian merupakan sarana untuk mengukur fakta-fakta yang diperoleh secara sistematis. Berdasarkan pendapat di atas, menggunakan instrumen penelitian merupakan salah satu sarana yang efektif guna mempermudah dalam mengukur fakta-fakta yang diperoleh agar lebih sistematis. Angket terbuka dan angket tertutup merupakan instrumen yang diperlukan dalam teknik pengumpulan data. Sugiyono (2017) mengungkapkan, angket ialah cara mengumpulkan data yaitu mengajukan pertanyaan-pertanyaan untuk responden agar memperoleh jawaban. Saat mengisi angket tertutup responden hanya memilih tanggapan yang telah disediakan. Sedangkan, responden harus mengisi tanggapan dengan kalimatnya sendiri saat mengisi angket terbuka.

Bahan ajar e-book praktikum dagang yang usai pengembangannya selanjutnya akan dilakukan penelaahan oleh penelaah ahli bidang agar bahan ajar $e$-book yang dikembangkan mendapat saran sebagai dasar revisi atau perbaikan, sehingga dapat dihasilkan bahan ajar $e$ book praktikum akuntansi perusahaan dagang yang memadai diterapkan dalam proses pembelajaran. Setelah didapatkan beberapa saran serta nasihat dari penelaah bidang dan dilakukan perbaikan, kemudian para ahli akan memvalidasi bahan ajar e-book guna memperoleh hasil interprestasi kelayakan bahan ajar e-book.

Lembar telaah para penelaah bidang berisi masukan dan kritik yang berguna untuk memperbaiki dan menyempurnakan $e$-book dari aspek isi, bahasa, penyajian, grafis dan desain. Sedangkan lembar validasi berisi kriteria penilaian menggunakan skala likert, kemudian hasil dari lembar validasi akan diolah dalam bentuk presentase dan diinterpretasikan sesuai tingkat kelayakan kesesuaian $e$-book praktikum perusahaan dagang dengan intrepretasi berikut. 
Tabel 1. Kriteria penilain dengan Skala Likert

\begin{tabular}{cc}
\hline Kriteria & Skor \\
\hline Sangat baik & 5 \\
\hline Baik & 4 \\
\hline Sedang & 3 \\
\hline Tidak Baik & 2 \\
\hline Sangat tidak baik & 1 \\
\hline Sumber: diadaptasi Riduwan (2016)
\end{tabular}

Data hasil validasi dikaji memakai rumus:

$$
\text { Persentase }=\frac{\text { Jumlsh Skor }}{\text { Jumlah Skor Maksimal }} \times 100 \%
$$

Tabel 2. Kriteria Interprestasi Validasi Ahli

\begin{tabular}{cc}
\hline Presentase & Kriteria Interprestasi \\
\hline $81 \%-100 \%$ & Sangat Layak \\
\hline $61 \%-80 \%$ & Layak \\
\hline $41 \%-60 \%$ & Cukup Layak \\
\hline $21 \%-40 \%$ & Tidak Layak \\
\hline $0 \%-20 \%$ & Sangat Tidak Layak \\
\hline
\end{tabular}

Sumber: diadaptasi dari Riduwan (2016)

Tabel 1 dan 2 digunakan sebagai pedoman dalam mencapai angka kriteria kelayakan bahan ajar $e$-book. Dikatakan layak apabila memperoleh nilai persentase $\geq 61 \%$ maka $e$-book layak diterapkan sebagai pendamping proses pembelajaran.

\section{HASIL DAN PEMBAHASAN}

\section{Proses Pengembangan Bahan Ajar E-Book Praktikum Perusahaan Dagang Berbasis Scientific Approach Sebagai Sumber Belajar Alternatif}

Tahap pendefinisian dimulai dari tahapan analisis ujung depan, langkah pertama yaitu menganalisis peserta didik untuk mengidentifikasi serta menetapkan pokok permasalahan dalam prosesnya yang terjadi pada guru dan peserta didik. Terdapat dua hal pokok yang menjadi penyebab utama kesulitan belajar yang dialami oleh peserta didik, pertama dari segi materi, untuk menyelesaikan siklus akuntansi perusahaan dagang peserta didik harus mengedepankan cara berpikir yang logis. Kedua, menurunnya semangat peserta didik untuk belajar lebih mandiri sebab ketersediaan bahan ajar yang mempermudah pemahaman dan meningkatkan semangat belajar dengan mandiri dan aktif peserta didik. Peserta didik selalu bergantung dari penjelasan guru dan cenderung ingin dituntun saat mengerjakan. Padahal menyajikan pembelajaran yang inovatif dan peserta didik menjadi titik pusatnya merupakan tugas seorang guru. Dalam tahapan ini diperoleh fakta serta solusi untuk mengembangkan $e$-book sesuai yang dibutuhkan.

Analisis tugas penerapannya dilakukan untuk merumuskan pengatahuan yang wajib dikuasai peserta didik supaya mempermudah merumuskan tugas-tugas yang perlu pada proses pembelajaran melalui hasil pengunaan e-book. E-book tersusun dengan dikembangkannya, memuat Kompetensi Dasar 3.9, 4.9, sampai Kompetensi Dasar 3.19 dan 4.19. Analisis konsep 
dibutuhkan untuk menentukan muatan e-book dikembangkan sesuai kompetensi inti dan konpetensi dasar untuk mempermudah pemahaman materi perta didik. Dengan melakukan perumusan tujuan pembelajaran mempermudah menentukan indikator pencapaian sesuai dengan KI dan KD. Tahap perancangan bertujuan untuk menguraikan pengembangan rancangan $e$-book. Bahan ajar $e$-book berpatokan terhadap ketentuan BSNP 2014 yang telah dimodifaksi peneliti. Setelah penyusunan format $e$-book, dilakukan proses perancangan awal $e$ book atau disebut dengan draft pertama. Pengenbangan bahan ajar e-book dirancang untuk dapat di akses secara offline melalui komputer, laptop maupun handphone.

Tahap selanjutnya yaitu proses $e$-book dikembangkan, pada tahapan ini draft pertama yang telah dirancang diberikan kepada para ahli untuk mendapatkan saran, nasihat dan kritikan perihal bahan ajar $e$-book guna memperbaiki bahan ajar yang dikembangkan langkah ini disebut proses telaah. Telaah ahli ini memerlukan lembar telaah yang berisi saran dan kritikan sebagai acuan melengkapi bahan ajar e-book dan menghasilkan data kualitatif. Ahli bidang materi memberikan saran untuk memperbaiki soal latihan serta menambah materi potongan dan syarat pembayaran secara kredit. Ahli bidang Bahasa memberikan saran memperbaiki susunan kata dan EYD dalam kalimat dan ahli bidang grafis memberikan saran untuk memperhatikan keterbacaan antar paragraf, membedakan warna objek, dan memperbaiki struktur penempatan judul, peta konsep dan sub bab. Setelah dilakukan telaah kemudian membenahi draft awal dan menghasilkan draft kedua yang akan diberikan kepada ahli untuk memvalidasi dengan memberikan skore 1 sampai 5 dan hasilnya akan diinterprestasikan untuk mendapatkan nilai kelayakan pada $e$-book praktikum akuntansi perusahaan dagang yang dikembangkan.

\section{Kelayakan Bahan Ajar E-book Praktikum Perusahaan Dagang Berbasis Scientific Approach Sebagai Sumber Belajar Alternatif}

Kelayakan e-book praktikum ini didapatkan dari hasil validator bidang yaitu validator bidang materi, validator bidang bahasa dan validator bidang grafis dengan melalui angket tertutup. Skor telah didapatkan dari lembar validasi tersebut akan di jumlahkan dan dianalisis memakai metode persentase dan kemudian diinterprestasikan. Berikut peyajian skor akhir dari nilai validator ahli bidang yang diberikan:

Tabel 3. Hasil.Validasi Kelayakan Materi

\begin{tabular}{cccc}
\hline No. & Subjek & Presentase & Interprestasi \\
\hline 1 & Kelayakan Isi & $86,9 \%$ & $\begin{array}{l}\text { Sangat } \\
\text { Layak }\end{array}$ \\
\hline 2 & $\begin{array}{l}\text { Kelayakan } \\
\text { Penyajian }\end{array}$ & $85 \%$ & $\begin{array}{l}\text { Sangat } \\
\text { Layak }\end{array}$ \\
\hline $\begin{array}{c}\text { Rata-Rata Kelayakan } \\
\text { Materi }\end{array}$ & $85,9 \%$ & $\begin{array}{l}\text { Sangat } \\
\text { Layak }\end{array}$ \\
\hline
\end{tabular}

Sumber: data diolah peneliti (2020)

Dari data tersebut, diketahui kelayakan isi $e$-book praktikum akuntansi perusahaan dagang berbasis scientific approach sebagai sumber belajar alternatif yang telah dikembangkan, meliputi cakupan materi, akurasi materi, kemutakhiran dan kontekstual materi yang di sajikan meperoleh hasil presentase $86,9 \%$ dengan kategori sangat layak. Kelayakan penyajian $e$-book praktikum akuntansi perusahaan dagang berbasis scientific approach sebagai sumber belajar aternatif yang dikembangkan, mencakup teknik penyajian bahan ajar, pendukung penyajian materi bahan ajar, dan penyajian bahan ajar dalam pembelajaran memperoleh rata-rata sebesar 85\% dengan kategori sangat layak. Hasil presentase validasi kelayakan materi tersebut merupakan hail rata-rata dua validator ahli bidang materi akuntansi yang berasal dari dosen $\mathrm{S} 1$ 
Pendidikan Akuntansi Unesa dan guru pengampu mata pelajaran praktikum akuntansi perusahaan dagang. Kesimpulan yang diperoleh ialah hasil validasi ahli bidang materi terhadap pengembangan materi e-book ialah "sangat layak" dengan memperoleh nilai rata-rata sebesar $85,9 \%$. Dikarenakan kelayakan materi mendapatkan hasil $\geq 81 \%$, maka e-book yang dikembangkan sesuai patokan standar BSNP (2014) yakni dari segi kelayakan isi dan kelayakan penyajian.

Tabel 4. Hasil Validasi.Kelayakan.Bahasa

\begin{tabular}{clcc}
\hline No. & \multicolumn{1}{c}{ Subjek } & Presentase & Interprestasi \\
\hline 1 & $\begin{array}{l}\text { Kesesuaian } \\
\text { dengan tingkat } \\
\text { Perkembangan } \\
\text { Peserta Didik }\end{array}$ & $90 \%$ & $\begin{array}{l}\text { Sangat } \\
\text { Layak }\end{array}$ \\
\hline 2 & Keterbacaan & $80 \%$ & Layak \\
\hline 3 & $\begin{array}{l}\text { Kemampuan } \\
\text { Memotivasi }\end{array}$ & $80 \%$ & Layak \\
\hline 4 & Kelugasan & $85 \%$ & $\begin{array}{l}\text { Sangat } \\
\text { Layak }\end{array}$ \\
\hline 5 & $\begin{array}{l}\text { Koherensi dan } \\
\text { Keruntutan Alur } \\
\text { Berfikir }\end{array}$ & $85 \%$ & $\begin{array}{l}\text { Sangat } \\
\text { Layak }\end{array}$ \\
\hline 6 & $\begin{array}{l}\text { Kesesuaian } \\
\text { dengan KBBI }\end{array}$ & $80 \%$ & Layak \\
\hline 7 & $\begin{array}{l}\text { Teknik } \\
\text { Penyajian }\end{array}$ & $85,9 \%$ & $\begin{array}{l}\text { Sangat } \\
\text { Layak }\end{array}$ \\
\hline Rata-Rata Kelayakan & $83,7 \%$ & Sangat \\
Bahasa & & Layak \\
\hline
\end{tabular}

Sumber: data diolah peneliti (2020)

Dari data tersebut, diketahui aspek kesesuaian dalam e-book praktikum akuntansi perusahaan dagang berbasis scientific approach sebagai sumber belajar alternative yang dikembangkan mencakup kesesuaian tingkat perkembangan peserta didik dan kesesuaian dengan tingkat perkembangan emosional peserta didik memperoleh hasil presentase sebesar 90\% dengan kategori sangat layak. Aspek keterbacaan mencakup keterpahaman peserta didik terhadap pesan yang disampaikan atau materi yang disajikan dalam bahan ajar e-book memperoleh hasil presentase sebesar 80\% dengan kategori layak. Aspek kemampuan memotivasi yang terdapat dalam bahan ajar e-book yang meliputi kemampuan memotivasi peserta didik untuk berpikir kritis memperoleh hasil presentasi sebesar $80 \%$ dengan kategori layak. Aspek kelugasan bahasa yang digunakan dalam bahan ajar e-book yang meliputi ketepatan struktur kalimat yang digunakan dan penggunaan istilah yang baku memperoleh hasil presentase $85 \%$ dengan kategori sangat layak. Aspek koherensi dan keruntutan alur berpikir yang digunakan dalam bahan ajar $e$-book menncakup aspek keruntutan dan keutuhan makna dalam antar bab, sub bab dan alenia memperoleh hasil presentase $85 \%$ dengan kategori sangat layak. Aspek kesesuaian penggunaan bahasa sesuai Kaidah Bahasa Indonesia dalam bahan ajar e-book mencakup aspek ketepatan penggunaan tata bahasa dan ketepatan ejaan yang digunakan memperoleh hasil presentase $80 \%$ dengan kategori layak. Aspek teknik penyajian bahan ajar $e$ book dalam penggunaan istilah, simbol/lambang yang mencakup konsistensi penggunaan istilah, konsistensi penggunaan simbol/lambang dan ketepatan penulisan nama ilmiah/asing memperoleh nilai hasil presentase sebesar $85,9 \%$ dengan kategori sangat layak. 
Berdasarkan aspek-aspek di atas dapat disimpulkan hasil validasi ahli bidang bahasa terhadap pengembangan bahan ajar e-book ialah "sangat layak" dengan memperoleh nilai ratarata sebesar 83,7\%. Dikarenakan kelayakan bahasa mendapatkan hasil $\geq 81 \%$, maka $e$-book dikembangkan telah sesuai dengan patokan standar BSNP (2014) yakni dari segi keserasian, keterbacaan, keterampilan memotivasi, kesederhanaan, keruntutan alur berpikir, dan teknik penyajian. Hasil presentase validasi kelayakan bahasa tersebut diperoleh dari validator ahli bidang bahasa dari dosen Fakultas Bahasa dan Seni Unesa yang andal dalam bidang tata Bahasa Indonesia

Tabel 5. Hasil Validasi Kelayakan Grafis

\begin{tabular}{clcc}
\hline No. & \multicolumn{1}{c}{ Subjek } & Presentase & Interprestasi \\
\hline 1 & $\begin{array}{l}\text { Ukuran Bahan } \\
\text { Ajar Ebook }\end{array}$ & $90 \%$ & $\begin{array}{l}\text { Sangat } \\
\text { Layak }\end{array}$ \\
\hline 2 & $\begin{array}{l}\text { Desain Cover } \\
\text { Bahan Ajar } \\
\text { Ebook }\end{array}$ & $85 \%$ & $\begin{array}{l}\text { Sangat } \\
\text { Layak }\end{array}$ \\
\hline 3 & $\begin{array}{l}\text { Desain Bagian } \\
\text { Isi Buku }\end{array}$ & $87 \%$ & $\begin{array}{l}\text { Sangat } \\
\text { Layak }\end{array}$ \\
\hline $\begin{array}{l}\text { Rata-Rata Kelayakan } \\
\text { Grafis }\end{array}$ & $87,3 \%$ & $\begin{array}{l}\text { Sangat } \\
\text { Layak }\end{array}$ \\
\hline
\end{tabular}

Sumber: data diolah peneliti (2020)

Data tersebut menunjukan kelayakan penyajian kegrafisan terhadap bahan ajar e-book praktikum akuntansi perusahaan dagang berbasis scientific approach sebagai sumber belajar alternatif yang dikembangkan, aspek kesesuaian ukuran bahan ajar e-book yang mencakup kesesuaian ukuran/format buku dengan standar ISO dan kesesuaian ukuran $e$-book dengan materi/isi buku memperoleh hasil presentase sebesar 90\% dengan kategori sangat layak. Aspek desain cover bahan ajar yang mencakup penempatan tata letak abahn ajar e-book (komposisi, kesatuan, keharmonisan, kekontrasan, unsur warna menampilkan pusat pandang yang baik dan jelas, seimbang dan seirama), tipografi cover bahan ajar e-book (unsur warna, ukuran huruf, kombinasi jenis huruf tidak berlebihan, sesuai isi/materi bahan ajar), ilustrasi cover bahan ajar e-book (mampu menggambarkan realita objek, proporsional bentuk, dan penggunan karakter objek), memperoleh hasil presentase sebesar $85 \%$ dengan kategori sangat layak. Aspek desain pada bagian isi buku yang meliputi tata letak isi e-book (proporsional, konsistensi, pola, pemisahan paragraph, jarak antar paragraph, spasi antar teks, dan penggunaan margin), tipografi isi bahan ajar $e$-book dan ilustrasi bahan ajar $e$-book, memperoleh hasil presentase sebesar $87 \%$ dengan kategori sangat layak.

Dari hasil presentase aspek-aspek di atas dapat disimpulkan validasi bidang grafis pada pengembangan bahan ajar e-book ialah "sangat layak" dengan memperoleh nilai rata-rata sebesar 87,3\%. Oleh sebab itu, e-book praktikum ini telah mencakup aspek kelayakan kegrafisan dengan berpatokan pada standar BSNP (2014) yakni dari segi ukuran bahan ajar, design cover dan design isi dan diperoleh rata-rata persentase $\geq 81 \%$. Hasil presentase validasi kelayakan grafis diperoleh dari validator ahli bidang dari dosen Fakultas Ilmu Pendidikan Unesa yang andal dibidang kegrafisan.

Tabel 6. Rekapitulasi Hasil Validasi Para Ahli

\begin{tabular}{crcc}
\hline No. & Subjek & Presentase & Interprestasi \\
\hline 1 & $\begin{array}{l}\text { Kelayakan } \\
\text { Materi }\end{array}$ & $85,9 \%$ & $\begin{array}{l}\text { Sangat } \\
\text { Layak }\end{array}$ \\
\hline 2 & Kelayakan & $83,7 \%$ & Sangat \\
\hline
\end{tabular}




\begin{tabular}{clcc}
\hline No. & \multicolumn{1}{c}{ Subjek } & Presentase & Interprestasi \\
\hline & Bahasa & & Layak \\
\hline 3 & Kelayakan & $87,3 \%$ & Sangat \\
& Grafis & & Layak \\
\hline $\begin{array}{c}\text { Rata-Rata Kelayakan } \\
\text { Bahan Ajar E-book }\end{array}$ & $85,6 \%$ & $\begin{array}{l}\text { Sangat } \\
\text { Layak }\end{array}$ \\
\hline
\end{tabular}

Sumber: data diolah peneliti (2020)

Berdasarkan ketiga tabel hasil validasi di atas diperoleh kategori "sangat layak" dari penilaian validator bidang materi, ahli bidang Bahasa, dan ahli bidang grafis dengan rata-rata 85,6\% mencakup komponen penyajian, isi, Bahasa dan kegafisan. Kesimpulan keseluruhan bahan ajar e-book praktikum perusahaan dagang berbasic scientific approach sebagai sumnber belajar alternatif yang dikembangkan sangat layak dipakai pada proses kegiatan belajar mengajar.

\section{SIMPULAN DAN SARAN Simpulan}

Berpatokan pada hasil penilitian dan pembahasan yang usai dilakukan, kesimpulan process pengenbangan bahan ajar e-book praktikum akuntansii perusahaan dagang berbasic scientific approach: (1) Proses pengembangan $e$-book praktikum akuntansi perusahaan dagang berpatokan pada model 4-D yang mengacu pada teori "Thiagarajan, Semmel and Semmel (Trianto, 2015). Memiliki prosedur atau alur yang tersistem serta karakteristik yang sama menjadi dasar penggunaan model 4-D tepat digunakan. Langkah penilitian terhenti pada langkah develop sebab adanya keterbatasan. (2) Kelayakan bahan ajar e-book praktikum akuntansi perusahaan dagang yang dikembangkan berdasar pada komponen penyajian, isi, Bahasa, dan kegrafisan diperoleh kategori sangat layak dari validator bidang materi, validator bidang Bahasa, ahli bidang grafis dengan rata-rata nilai $85,6 \%$. Sehingga $e$-book praktikum akuntansi perusahaan dagang efektif dipakai pada proses pembelajaran.

\section{Saran}

Berpatokan pada hasil dan analisis penelitian, terdapat beberapa point yang disarankan diantaranya (1) Oleh karena tidak dilakukannya langkah disseminate dan tidak dilakukannya uji coba terhadap peserta didik karena sesuatu hal pada proses pengembangan bahan ajar $e$-book praktikum praktikum akunatansi perusahaan ini maka perlu adanya penelitian lanjutan untuk menguji efisiensi $e$-book terhadap proses pembelajaran dan untuk mendapati respon peserta didik terhadap bahan ajar $e$-book yang telah dikembangkan. (2) Pengembangan bahan ajar $e$ book praktikum akunntansi perusahaan dagang berbasis scientific approach sebagai sumbeer belajar alternatif dapat diterapkan pada pembelajaran kurikulum 2013, sehingga diharapkan adanya penelitian lebih lanjut mengenai penerapan menggunakan model pembelajaran yang berbeda. (3) pengembangan bahan ajar $e$-book praktikum akuntansi perusahaan dagang berbasis scientific approach sebagai sumber belajar alternatif kurang mempertimbangkan tampilan $e$ book yang muncul pada layar handphone (HP), sehingga peneliti berharap untuk peneliti pengembangan produk yang sejenis lebih memperhatikan tampilan layar yang dapat diperbesar dan diperkecil sesuai dengan ukuran layar handphone (HP).

\section{DAFTAR PUSTAKA}

Atma Dirgatama, C. H., Peserta didikndari, S., \& Indrawati, C. D. S. (2017). The Effectiveness of Archived E-Book Based Curriculum 2013 as an Effort to Improving Learning Outcomes 
in Vocational School. Journal of Education and Learning (EduLearn), 11(3), 251. https://doi.org/10.11591/edulearn.v11i3.5936

BSNP. (2014a). Naskah Akademik Instrumen Penilaian Buku Teks Kelayakan Kegrafikan. Jakarta: BSNP.

BSNP. (2014b). Naskah Akademik Instrumen Penilaian Buku Teks Kelompok Perminatan Ekonomi. Jakarta: BSNP.

Dewi, D., \& Suci, R. (2017). Pengembangan Bahan Ajar E-Book Interaktif Materi Jurnal Khusus Akuntansi Perusahaan Dagang Berbasis Scientific Approach Sebagai Sumber Belajar Alternatif Kelas XI SMK Negeri 2 Buduran Sidoarjo Devita Rezalia Dewi Suci Rohayati Abstrak. Jurnal Pendidikan Akuntansi, 01 Nomor 0, 0-216.

Fadhilah, N., \& Susilowibowo, J. (2019). Pengembangan Buku Ajar Akuntansi Berbasis Scientific Approach Pada Materi Proses Pencatatan Dan Pengikhtisaran Perusahaan Manufaktur Mata Pelajaran Akuntansi Dasar Kelas X Akuntansi Dan Keuangan Lembaga Smk Negeri 1 Bangkalan. Jurnal Pendidikan Akuntansi, 07 Nomor 0, 372-377.

Hasyim, A. (2015). Metode Penelitian dan Pengembangan di Sekolah. Yogyakarta: Media Akademi.

Kemendikbud. (2018). Salinan Lampiran VI Peraturan Menteri Pendidikan dan Kebudayaan Nomor 34 Tahun 2018 Tentang Standar Nasional Pendidikan Sekolah Menengah Kejuruan/Madrasah Aliyah Kejuruan, 1-550. Retrieved from jdih.kemendikbud.go.id

Prastowo, A. (2015). Panduan Kreatif Membuat Bahan Ajar Inovatif (D. Wijaya, ed.). Yogyakarta: Diva Press.

Pratiwi, A. Z. R. (2019). Pengembangan Bahan Ajar E-Book Interaktif Pendekatan Kurikulum 2013 Mata Pelajaran Praktikum Akuntansi Lembaga/Instansi Pemerintah Kelas XI AKL SMK Negeri 1 Lamongan. Jurnal Pendidikan Akuntansi, 07(02), 145-151.

Rahmawati, S., \& Susanti. (2019). Pengembangan Bahan Ajar E-Book Pada Mata Pelajaran Praktikum Akuntansi Lembaga Berbasis Kontekstual Untuk SMK. Jurnal Pendidikan Akuntansi, 07 Nomor 0, 383-391.

Raihan, S., Haryono, \& Ahmadi, F. (2018). Development of Scientific Learning E-Book Using 3D Pageflip Professional Program. Innovative Journal Of Curriculum and Educational Technology, 7(1), 7-14.

Riduwan. (2016). Skala Pengukuran Variabel-Variabel Penelitian. Bandung: CV.Alfabeta.

Sugiyono. (2016). Metode Penelitian Pendidikan Pendekatan Kuantitatif, Kualitatif dan R\&D. Bandung: CV. Alfabeta.

Sugiyono. (2017). Metode Penelitian Pendidikan: Pendekatan Kuantitatif, Kualitatif, dan $R \& D$. Bandung: $\mathrm{CV}$. Alfabeta.

Supanda, A. (2013). Simulasi Digital Buku Digital. Jakarta: Guruvalah.

Trianto. (2015). Mendesain Model Pembelajaran Inovatif, Progresif dan Kontekstual. Jakarta: Prenadamedia Group.

Undang-Undang Republik Indonesia Nomor 20 Tahun 2003. (n.d.). Sistem Pendidikan Nasional. 